\title{
Growth in Children with Thalassaemia Major and Effect of Two Different Transfusion Regimens
}

\author{
C. G. D. BROOK, E. N. THOMPSON, ${ }^{\star}$ W. C. MARSHALL, and R. H. WHITEHOUSE \\ From The Hospital for Sick Children, Great Ormond Street, and Institute of Child Health, University of London
}

The belief that children with thalassaemia major are small is common, but few detailed studies have been recorded. Johnston and Krogman (1964) claimed that growth and skeletal maturity were retarded; however, the majority of patients were seen only once. Wolman (1964), as a result of a cross-sectional study, concluded that children treated with high-level transfusion seemed in better health and grew more normally than those transfused at lower levels. He postulated that chronic hypoxia was more significant than iron overload in limiting growth in these patients. Johnston, Hertzog, and Malina (1966) in a longitudinal study confirmed that growth and skeletal maturity were delayed after the age of 4 years, and found that the pubertal growth spurt did not occur. They showed that high-level transfusion did not affect any of these parameters.

This study reports rates of growth in 28 Cypriot children with thalassaemia major, who were under regular supervision for periods ranging from 2 to 12 years. In 20 of them comparison was made to determine whether high-level transfusion altered the growth pattern in the individual concerned.

\section{Material and Methods}

The 12 boys and 16 girls attended the out-patient department at least once a month, when height and weight were measured and $\mathrm{Hb}$ estimated. Before 1966, transfusions were given when the $\mathrm{Hb}$ level had fallen to $4-6 \mathrm{~g} . / 100 \mathrm{ml}$. (low level); since then transfusions have been given at $\mathrm{Hb}$ levels of $8 \cdot 8-9 \cdot 4 \mathrm{~g}$. $/ 100 \mathrm{ml}$. (high level), attempting to raise the $\mathrm{Hb}$ to $14.5 \mathrm{~g} . / 100 \mathrm{ml}$.

Height was plotted on the standard charts for British children (Tanner, Whitehouse, and Takaishi, 1966) and the average centile position read off by eye from the curve for the years before and the two years after institution of high-level transfusion. Height velocities were calculated from the observed measurements at two years and one year before high-level transfusion had

Received March 11, 1969

* Present address: Department of Child Health, Welsh National School of Medicine, Cardiff. started and one year and two years after. The velocity of each of the two years before and of the two years after was recorded as a fraction of the expected (i.e. 50th centile) height velocity for the chronological age, and the average for the two periods was calculated in each case.

Skeletal maturity was assessed by examination of the hand and wrist $x$-ray immediately before the high-level transfusion regimen and two years later. The bone age was calculated by the Tanner-Whitehouse method (Tanner, Whitehouse, and Healy, 1962) and is expressed as a fraction of the chronological age.

\section{Results}

The serial growth data are shown in Tables I and II and Fig. 1-4.

As can be seen from the Tables and from the composite growth charts the children have grown normally. Only 3 out of 28 are beneath the 10th centile. Growth velocity and bone age are also within the normal range. However, in all three cases old enough for the pubertal growth spurt to be expected, it appears to be delayed (Fig. 1 and 2). Clinical examination confirms that puberty is delayed, and this is reflected in the skeletal maturity scores of the older children (Fig. 3 and 4).

Table I shows the growth data on 20 children on two different transfusion regimens. Though there was a marked difference in the average haemoglobins at the time of transfusion in the two periods studied, high-level transfusion has made no significant difference to the parameters of growth studied in the group as a whole. However, expected velocity figures are difficult to apply to the three oldest children with delayed puberty, and statistical examination of the height velocities of the remaining 17 children shows a significant $(p=<0.01)$ decrease during the two years of high-level transfusion.

\section{Discussion}

In this series prepubertal growth was observed to be normal, and the 'fall-off' in growth after 
TABLE I

Growth Data and Pretransfusion Hb Levels of 20 Children with Thalassaemia Major on Two Transfusion Regimens*

\begin{tabular}{|c|c|c|c|c|c|c|c|c|c|c|c|}
\hline \multirow[t]{2}{*}{$\begin{array}{l}\text { Case } \\
\text { No. }\end{array}$} & \multirow[t]{2}{*}{$\begin{array}{l}\text { Year of } \\
\text { Birth }\end{array}$} & \multirow[t]{2}{*}{$\begin{array}{l}\text { Splen- } \\
\text { ectomy }\end{array}$} & \multirow[t]{2}{*}{$\begin{array}{l}\text { Years of } \\
\text { Follow- } \\
\quad \text { up }\end{array}$} & \multicolumn{2}{|c|}{$\begin{array}{c}\text { Mean } \\
\text { Height Centile }\end{array}$} & \multicolumn{2}{|c|}{$\begin{array}{l}\text { Velocity Expressed } \\
\text { as Fraction of } \\
\text { Expected Velocity } \\
\text { for Age }\end{array}$} & \multicolumn{2}{|c|}{$\begin{array}{l}\text { Bone Age Expressed } \\
\text { as Fraction of } \\
\text { Chronological Age }\end{array}$} & \multicolumn{2}{|c|}{$\begin{array}{l}\text { Average } \mathrm{Hb} \\
\text { at Transfusion } \\
(\mathrm{g} . / 100 \mathrm{ml} .)\end{array}$} \\
\hline & & & & Pre '66 & Post '66 & Pre '66 & Post '66 & 1966 & 1968 & Pre '66 & Post '66 \\
\hline $\begin{array}{c}\text { Bovs } \\
1 \\
2 \\
3 \\
4 \\
5 \\
6 \\
7 \\
8 \\
9 \\
10 \\
11 \\
\\
\text { Girls } \\
13 \\
14 \\
15 \\
16 \\
17 \\
18 \\
19 \\
20 \\
21\end{array}$ & $\begin{array}{l}1952 \\
1957 \\
1957 \\
1957 \\
1958 \\
1958 \\
1959 \\
1959 \\
1960 \\
1962 \\
1962\end{array}$ & $\begin{array}{l}1956 \\
1958 \\
1959 \\
1964 \\
1964\end{array}$ & $\begin{array}{r}12 \\
9 \\
6 \\
7 \\
5 \\
8 \\
7 \\
7 \\
6 \\
5 \\
6\end{array}$ & $\begin{array}{r}25 \\
75 \\
75 \\
75 \\
1 \\
20 \\
45 \\
75 \\
25 \\
50 \\
65\end{array}$ & $\begin{array}{r}3 \dagger \\
70 \\
90 \\
75 \\
1 \\
10 \\
30 \\
80 \\
30 \\
60 \\
65\end{array}$ & $\begin{array}{l}0.59 \\
1 \cdot 10 \\
1 \cdot 47 \\
1 \cdot 17 \\
0 \cdot 83 \\
0 \cdot 78 \\
1 \cdot 07 \\
1 \cdot 18 \\
0 \cdot 82 \\
1 \cdot 18 \\
1 \cdot 10\end{array}$ & $\begin{array}{l}0.82 \\
0.65 \\
1.24 \\
0.92 \\
0.73 \\
0.78 \\
0.65 \\
1 \cdot 13 \\
1.20 \\
1.06 \\
0.99\end{array}$ & $\begin{array}{l}0.99 \\
1.38 \\
- \\
- \\
- \\
\overline{1} \cdot 23 \\
1 \cdot 25 \\
1 \cdot 10 \\
0.80 \\
1 \cdot 48 \\
\\
- \\
0.91 \\
1 \cdot 11 \\
1.13 \\
0.79 \\
1.42 \\
1.04 \\
1.09 \\
0.71\end{array}$ & $\begin{array}{l}0 \cdot 90 \\
1 \cdot 22 \\
1 \cdot 22 \\
1 \cdot 14 \\
0 \cdot 91 \\
1 \cdot 00 \\
1 \cdot 19 \\
1 \cdot 31 \\
1 \cdot 08 \\
1 \cdot 12 \\
1 \cdot 36\end{array}$ & $\begin{array}{l}6 \cdot 4 \\
6 \cdot 1 \\
5 \cdot 3 \\
4 \cdot 6 \\
5 \cdot 5 \\
4 \cdot 0 \\
5 \cdot 9 \\
5 \cdot 3 \\
5 \cdot 9 \\
5 \cdot 2 \\
5 \cdot 6\end{array}$ & $\begin{array}{l}9 \cdot 0 \\
9 \cdot 5 \\
9 \cdot 8 \\
9 \cdot 0 \\
8 \cdot 1 \\
8 \cdot 7 \\
8 \cdot 4 \\
8 \cdot 1 \\
8 \cdot 9 \\
9 \cdot 2 \\
9 \cdot 6\end{array}$ \\
\hline & $\begin{array}{c}\text { Mean } \\
\text { S E }\end{array}$ & & $6 \cdot 75$ & $\begin{array}{r}51 \cdot 55 \\
5 \cdot 69\end{array}$ & $\begin{array}{r}46 \cdot 05 \\
6 \cdot 17\end{array}$ & $\begin{array}{l}1 \cdot 02 \\
0 \cdot 057\end{array}$ & $\begin{array}{l}0.92 \\
0.05\end{array}$ & $\begin{array}{l}1 \cdot 095 \\
0 \cdot 06\end{array}$ & $\begin{array}{l}1 \cdot 097 \\
0 \cdot 036\end{array}$ & $\begin{array}{l}5 \cdot 70 \\
0 \cdot 15\end{array}$ & $\begin{array}{l}9 \cdot 03 \\
0 \cdot 13\end{array}$ \\
\hline
\end{tabular}

* Before 1966 transfusion given when $\mathrm{Hb}$ had fallen to 4-6 g./100 ml; after $1966 \mathrm{when} \mathrm{Hb}$ had fallen to 8.8-9.4 g./100 ml.

† Delayed puberty.

the age of 4 years recorded by Johnston et al. (1966) was not seen. Skeletal maturation was also normal in the prepubertal children. We have confirmed, in 2 girls and 1 boy, that adolescent growth spurt and puberty are delayed when compared to British standards. Unfortunately no comparable standards in growth to puberty are available for these children, all of whom are Cypriot. However, the fact that the growth rates in these patients are comparable with the British standards

TABLE II

Growth Data of 8 Children with Thalassaemia Major

\begin{tabular}{|c|c|c|c|c|}
\hline Case No. & $\begin{array}{l}\text { Year of } \\
\text { Birth }\end{array}$ & $\begin{array}{c}\text { Years of } \\
\text { Follow-up }\end{array}$ & $\begin{array}{l}\text { Mean } \\
\text { Height Centile }\end{array}$ & $\begin{array}{l}\text { Velocity } \\
\text { Average for } \\
\text { 1966-68 }\end{array}$ \\
\hline \multirow{3}{*}{\begin{tabular}{ll}
\multicolumn{1}{c}{ Boys } & \\
& \\
& \\
Girls & \\
22 \\
23 \\
24 \\
25 \\
26 \\
27 \\
28
\end{tabular}} & 1961 & 3 & 60 & $0 \cdot 84$ \\
\hline & $\begin{array}{l}1960 \\
1960 \\
1961 \\
1963 \\
1964 \\
1965 \\
1966\end{array}$ & $\begin{array}{l}5 \\
4 \\
3 \\
2 \\
2 \\
2 \\
2\end{array}$ & $\begin{array}{r}10 \\
1 \\
40 \\
25 \\
50 \\
50 \\
50\end{array}$ & $\begin{array}{l}0 \cdot 79 \\
0 \cdot 88 \\
1 \cdot 08 \\
0 \cdot 82 \\
1 \cdot 06 \\
0 \cdot 85 \\
0.92\end{array}$ \\
\hline & Mean & $2 \cdot 9$ & 36 & 0.90 \\
\hline
\end{tabular}




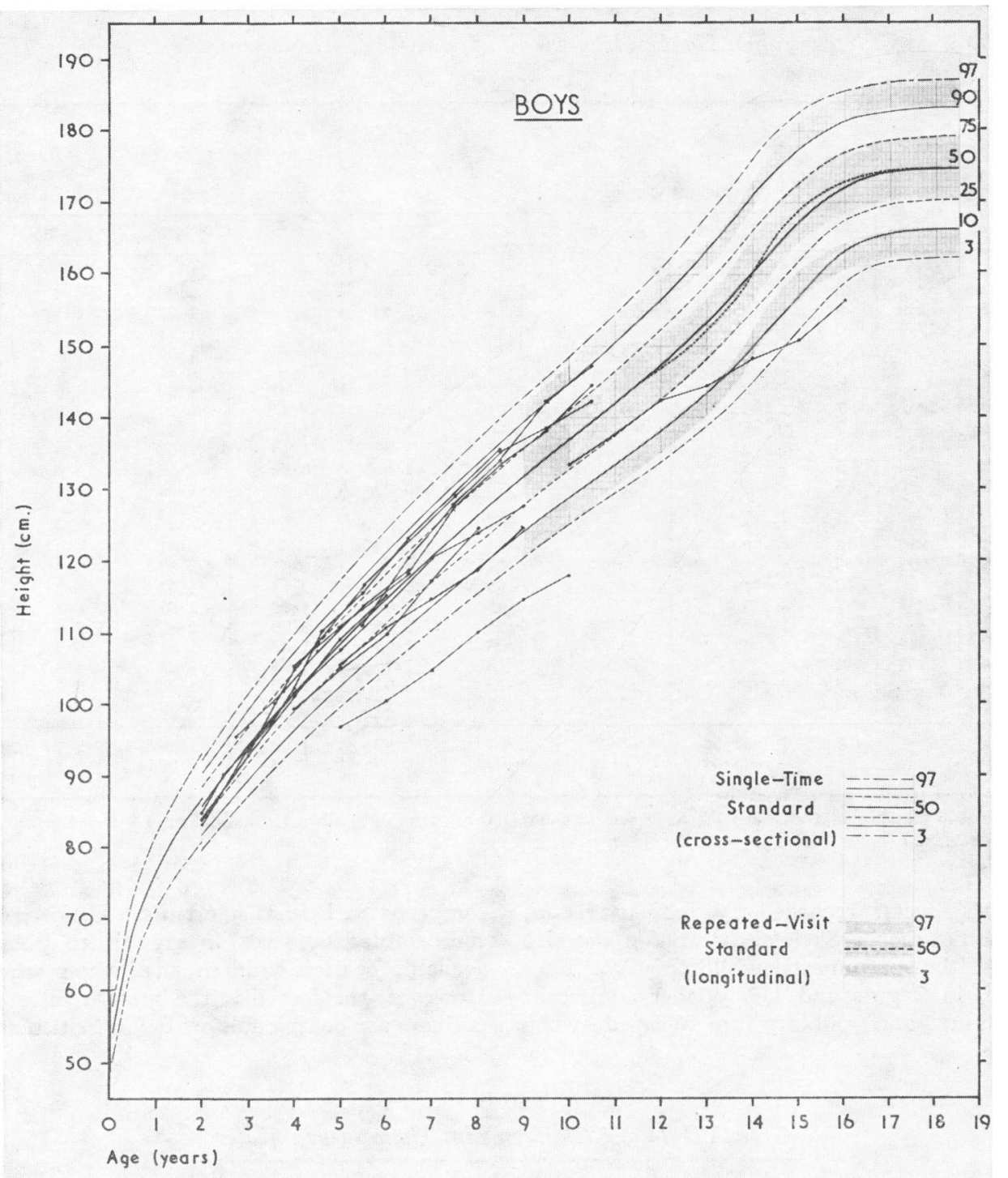

FIG. 1.-Composite growth chart for 12 boys with thalassaemia major.

suggests that the pubertal delay may be significant in relation to their disease rather than a feature of Cypriot children in general.

The finding that high-level transfusion depresses prepubertal growth velocity must be taken as a drawback to this regimen. Though the parents consider that the children are subjectively better with high-level transfusion, this has to be balanced against the adverse effects on growth.
We consider, therefore, that as far as growth is concerned transfusions should be given in order to maintain well-being, and $\mathrm{Hb}$ should be maintained at not less than $6.6 \mathrm{~g} . / 100 \mathrm{ml}$.

\section{Summary}

Longitudinal data on height, growth, and skeletal maturation on 28 children with thalassaemia major 


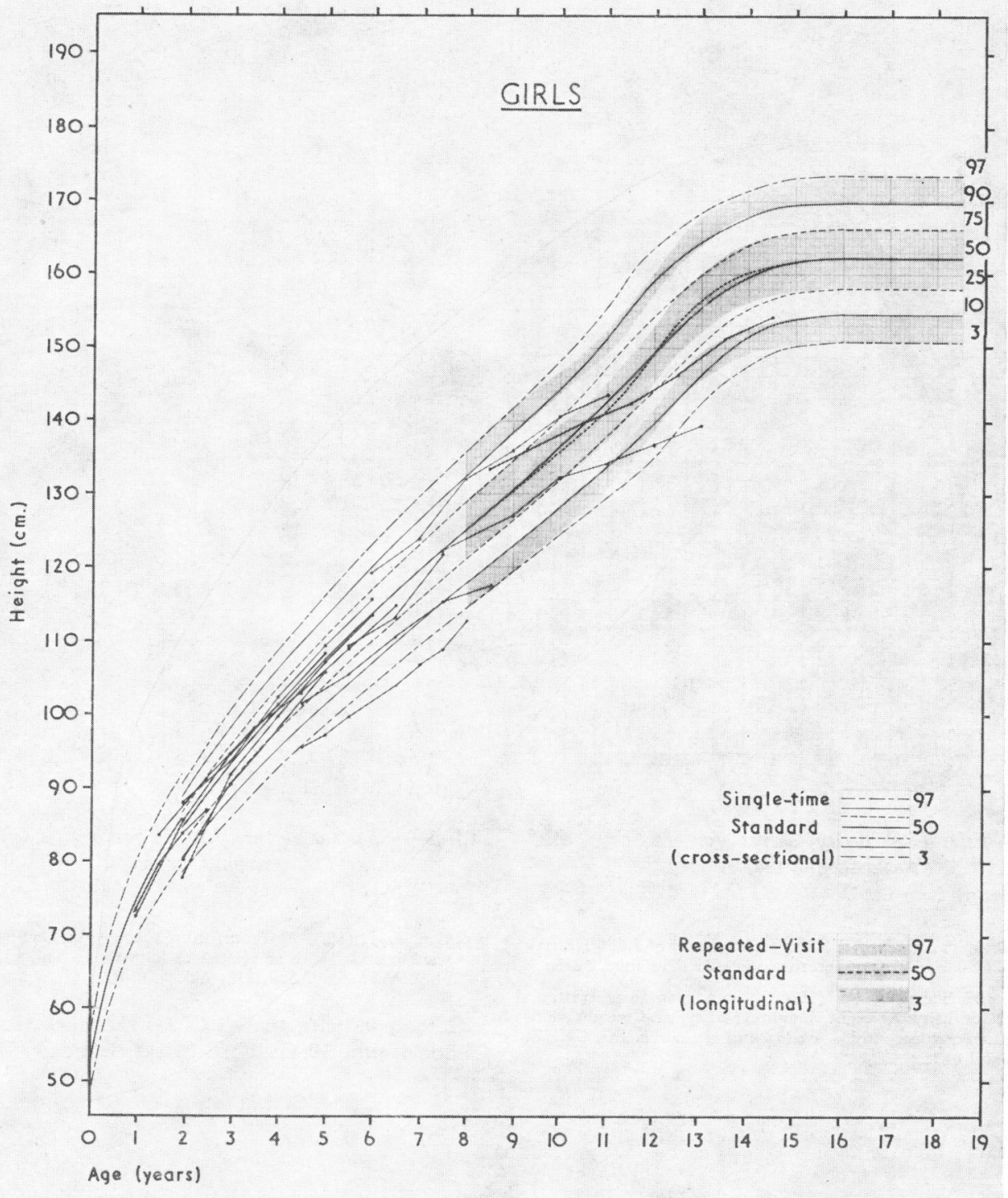

FIG. 2.-Composite growth chart for 16 girls with thalassaemia major.

are reported. Prepubertal growth and skeletal maturity were within normal limits, but in 3 children where puberty would have been expected, it appeared to be delayed.

In 20 children, in whom a comparison of height velocity before and after a high-level transfusion regimen was possible, the latter was associated with a significant depression of prepubertal growth. So far as growth is concerned, high-level transfusion is of no advantage and may be deleterious.
We are grateful to Professor J. M. Tanner of the Institute of Child Health for his advice and assistance.

\section{REFERENCES}

Johnston, F. E., Hertzog, K. P., and Malina, R. M. (1966). Longitudinal growth in thalassemia major. Amer. F. Dis. Child., 112, 396.

—, and Krogman, W. M. (1964). Patterns of growth in children with thalassemia major. Ann. N.Y. Acad. Sci., 119, 667.

Tanner, J. M., Whitehouse, R. H., and Healy, M. J. R. (1962). A New System for Estimating Skeletal Maturity from the Hand 




Fig. 3.-Skeletal maturity scores for 11 boys with thalassaemia major.

and Wrist, with Standards Derived from a Study of 2,600 Healthy British Children. Centre Internationale de l'Enfance, Paris.

- - - and Takaishi, M. (1966). Standards from birth to maturity for height, weight, height velocity, and weight velocity: British children, 1965. Parts I and II. Arch. Dis. Childh., 41, 454 and 613.
FIG. 4.-Skeletal maturity scores for 9 girls with thalassaemia major.

Wolman, I. J. (1964). Transfusion therapy in Cooley's anemia: growth and health as related to long-range hemoglobin levels. Ann. N.Y. Acad. Sci., 119, 736.

Correspondence to Dr. C. G. D. Brook, Institute of Child Health, 30 Guilford Street, London, W.C.1. 